\title{
FROM THE CHIEF EDITOR
}

DOI: $10.15838 / \mathrm{esc} / 2015.2 .38 .1$

UDC 330.341, LBC 65.050.11

(C) Ilyin V.A.

\section{Halfway to a fourth presidential term}

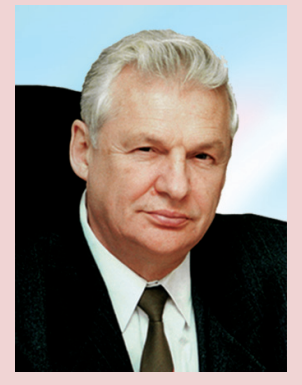

\section{Vladimir Aleksandrovich}

ILYIN

Doctor of Economics, Professor, Honoured Scientist of the Russian Federation,

Director, Federal State Budgetary Institution of Science Institute of Socio-Economic

Development of Territories of Russian Academy of Science (56A, Gorky Street,

Vologda, 160014, Russian Federation, ilin@vscc.ac.ru)

May 2015 is marked by the end of the first half of Vladimir Putin' six-year presidency. Today we can say with confidence that since 1991 there has been no such high support of the top state official for the entire period of the modern history of the Russian Federation.

According to the data of sociological surveys using indicators of the degree of approval of the performance of the President of the Russian Federation it is possible to assess the level and dynamics of public administration efficiency in the country as a whole.

The graph (figure) shows that according to the surveys, the level of approval of President Boris Yeltsin in 1996 was 27\%, in $1998-16.3 \%$ and in $1999-8.4 \%$. Such estimates are understandable, because the period of B.N. Yeltsin's presidency
(1991-1999) was accompanied by a drastic reduction of all the main indicators of production in the real sector of the economy, by an unprecedented decrease in the standard of living and quality of life, in hyperinflation, in the breakdown of the budget system and money circulation. Ultimately, the so-called "shock therapy" led to a sovereign default in August 1998. The actual parameters of that economic and social disaster can be seen in table 1 .

After Boris Yeltsin left the office of President in December 31, 1999, Vladimir Putin, who had been Prime Minister since August 1999, was elected President of Russia in March 2000. And in the first year of his presidency the level of approval of the RF President's performance by the residents of the Russian Federation reached $80 \%$. 


\section{Assessment of the RF President's performance}

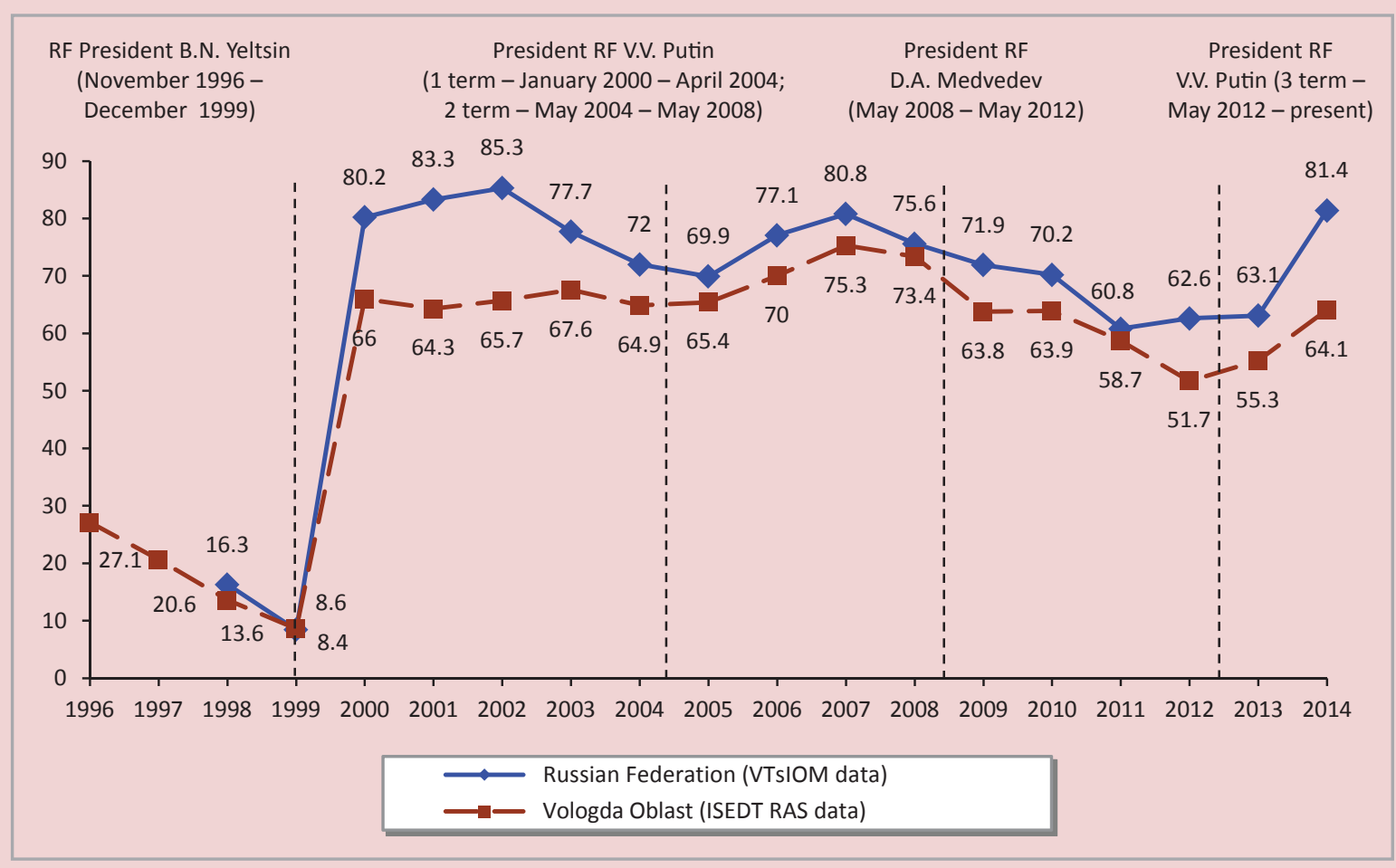

Dynamics of the level of approval of the RF President's performance by the residents of the Russian Federation and the Vologda Oblast (\% of the number of respondents)

Table 1. Dynamics of the main macroeconomic indicators of the Russian Federation in 1991-1998

\begin{tabular}{|l|c|c|c|c|c|c|c|c|}
\hline \multirow{2}{*}{\multicolumn{1}{|c|}{ Indicator }} & \multicolumn{7}{c|}{ Year } \\
\cline { 2 - 11 } & 1991 & 1992 & 1993 & 1994 & 1995 & 1996 & 1997 & 1998 \\
\hline Gross domestic product, in \% to 1990 & 95 & 81.2 & 74.2 & 67.4 & 62 & 59.8 & 60.6 & 57.4 \\
\hline Industrial output, in \% to 1990 & 92 & 75 & 65 & 51 & 48.6 & 44.9 & 45.4 & 43.2 \\
\hline Agricultural output, in \% to 1990 & 95.5 & 86.5 & 82.7 & 72.8 & 67 & 63.6 & 64.1 & 55.1 \\
\hline Investments in fixed capital, in \% to 1990 & 85.1 & 51.3 & 45.3 & 34.3 & 30.8 & 25.3 & 24 & 21.1 \\
\hline $\begin{array}{l}\text { Real disposable incomes of the population, in \% } \\
\text { to 1990 }\end{array}$ & & 60.9 & 70.9 & 80 & 67.1 & 67.7 & 72 & 68 \\
\hline $\begin{array}{l}\text { Index of inflation, December to the December of } \\
\text { the previous year, times }\end{array}$ & 2.6 & 26.1 & 8.4 & 3.1 & 2.3 & 1.2 & 1.11 & 1.84 \\
\hline $\begin{array}{l}\text { Compiled with the use of the following source: Livshits V.N. Sistemnyi analiz rynochnogo reformirovaniya nestatsionarnoi ekonomiki } \\
\text { Rossii [System Analysis of Market Reforms of Russia's Unsteady Economy. 1992-2013]. Moscow: LENAND, 2013. Pp. 107-109. }\end{array}$ \\
\hline
\end{tabular}


Table 2. Dynamics of the main macroeconomic indicators of the Russian Federation in 2000-2007

\begin{tabular}{|l|c|c|c|c|c|c|c|c|}
\hline \multirow{2}{*}{\multicolumn{1}{|c|}{ Indicator }} & \multicolumn{7}{c|}{ Year } \\
\cline { 2 - 9 } & 2000 & 2001 & 2002 & 2003 & 2004 & 2005 & 2006 & 2007 \\
\hline Gross domestic product, in \% to 2000 & 100.0 & 105.1 & 109.9 & 118.0 & 125.5 & 135.5 & 143.8 & 151.3 \\
\hline Industrial output, in \% to 2000 & 100.0 & 102.9 & 106.1 & 115.5 & 124.7 & 131.0 & 139.3 & 148.7 \\
\hline Agricultural output, in \% to 2000 & 100.0 & 106.9 & 107.9 & 107.8 & 110.3 & 112.1 & 115.4 & 119.2 \\
\hline Investments in fixed capital, in \% to 2000 & 100.0 & 117.4 & 120.7 & 135.9 & 154.5 & 170.2 & 198.6 & 246.0 \\
\hline $\begin{array}{l}\text { Real disposable incomes of the population, in \% to } \\
2000\end{array}$ & 100.0 & 110.1 & 122.0 & 139.8 & 155.5 & 192.8 & 220.0 & 247.7 \\
\hline $\begin{array}{l}\text { Index of inflation, December to the December of the } \\
\text { previous year, in \% }\end{array}$ & 120.2 & 118.6 & 115.1 & 112.0 & 111.7 & 110.9 & 109.0 & 111.9 \\
\hline $\begin{array}{l}\text { Compiled with the use of the following source: Livshits V.N. Sistemnyi analiz rynochnogo reformirovaniya nestatsionarnoi ekonomiki } \\
\text { Rossii [System Analysis of Market Reforms of Russia's Unsteady Economy. 1992-2013]. Moscow: LENAND, 2013. Pp. 107-109. }\end{array}$ \\
\hline
\end{tabular}

Vladimir Putin's work was marked by a system of political efforts aimed to strengthen the statehood, and stop disintegration processes in the country. A package of measures to improve the economy of the country was started to be implemented. In particular, export duties were restored, mineral extraction tax was introduced, which dramatically increased federal budget revenues and provided the basis for conducting large-scale social events. A sharp improvement in the economic and social situation in the country (tab. 2) contributed greatly to the victory of Vladimir Putin in the presidential elections in 2004.

In the next four years Vladimir Putin continued the course focused on economic recovery. And the goal was achieved. And what is more important, the real incomes of the population during V. Putin's presidency increased in 2.5 times; this fact ensured the high level of approval of the President's performance.
The second important factor in ensuring the high level of approval was Vladimir Putin's desire to pursue an independent foreign policy and foreign economic policy in the interests of state security of the Russian Federation with the use of all means available.

February 10, 2007, speaking at the Munich conference on security policy, Vladimir Putin stated clearly that the unipolar model is not only unacceptable, but also impossible in the modern world. He stressed that the entire legal system of one state, primarily, the United States, has overstepped its national borders in all spheres: in economy, politics, humanitarian sphere, and it is imposed on other countries. Vladimir Putin voiced the firm position of Russia to pursue its independent foreign policy consistent with the thousand-year historical tradition and practice of our country. This formulation of the question (especially in the U.S. political circles) was used by the West as 
a pretext for resuming the cold war against Russia, which increases international tension and threatens with the outbreak of a large-scale hot war ${ }^{1}$.

The second term of Vladimir Putin's presidency expired in 2008 . He did not want to change the Constitution, which estab-lishes a limit of two consecutive presidential terms; so he nominated Dmitry Medvedev, Head of the Administration and Deputy Prime Minister, as his successor. To win the elections the presidential candidate had only to express the intention to follow the course laid out by Putin. As for Vladimir Putin, he became Prime Minister and leader of the ruling party "United Russia".

Unfortunately, the progressive movement of the country during D. Medvedev's presidency slowed down. His commitment to liberal ideas in public administration resulted in the widening of the gap in economic development between Russia and the world's leading countries.

At the end of 2008 and during 2009 Russia's economy had to face the global financial crisis, which was much more harmful for Russia than for Western and developing countries.

The residents of Russia assessed the 2008-2011 performance of President Dmitry Medvedev significantly lower as compared to the level reached by Vladimir Putin in 2007. The total loss amounted

\footnotetext{
The issues related to the formation of a multipolar world and the place of Russia in it were substantially continued by President Vladimir Putin in September 2013 at the session of the Valdai International Discussion Club.
}

to 20 percentage points: from $80 \%$ of the respondents who approved Vladimir Putin's performance in 2007 to $60 \%$ of those who approved Dmitry Medvedev's activity in 2011.

As Prime Minister and leader of the ruling party, Vladimir Putin assumed full responsibility for organizing the response to the Georgian aggression in South Ossetia in August 2008 and for subsequent peaceful resolution of the conflict.

Vladimir Putin's actions were crucial in organizing Russia's recovery from the global crisis of 2008-2009. But that did not solve the main problem of the period - the shift of the real sector of the economy to the new industrialization that provides the necessary pace of modernization of the country in order to strengthen its security in all directions.

The point of no return in a unipolar world for Russia was passed after the Munich Speech of Vladimir Putin as President of Russia. Therefore, the United States of America and the so-called West did everything to ensure that Vladimir Putin was not elected President for the third term. An attempt was made with the help of various non-governmental opposition forces to organize a protest on Bolotnaya Square in Moscow in December 2011, after the elections to the State Duma; but this attempt did not give the opponents the results they desired.

After a landslide victory at the presidential election in March 2012, Vladimir Putin continued Russia's independent foreign policy; and the U.S. and its Western 
partners responded by sharply aggravating the situation in Ukraine, creating a hotbed of internal Ukrainian conflict and trying to involve Russia into this conflict at the official level; it would give them ground to accuse our country of aggression and apply all international sanctions to Russia.

The President of the Russian Federation manages to block the most negative options in the development of events in Ukraine in the conditions, when the ruling clans of this country have practically unleashed a civil war. Currently, after the Minsk Agreements of the Norman Quartet, the level of escalation of the conflict decreased slightly.

However, it should be recognized that after three years of the current term of Vladimir Putin's presidency, the situation in the economy and social life of the country remains extremely tense.

The program objectives of his activities as President, V.V. Putin outlined in his decrees of May 7, 2012 that were adopted immediately after the inauguration. The decrees contain a lot of target indicators, including the growth of real wages by 1.5 times by 2018 , the provision of $60 \%$ of the Russian families with affordable housing by 2020 , the creation of 25 million highperformance jobs, the upgrading of the army by $70 \%$, the increase in the share of investment in GDP to $27 \%$ in 2018. The main goal of the May Decrees consists in solving the problem of substantial increase of wages in the public sector.
These targets can be achieved only on the basis of advanced economic growth. And the conditions to ensure this growth are actually becoming more and more complicated. Russia has been in a state of autonomous recession since 2009 .

There is a decline in the purchasing power of the main categories of national economy - government, business, and households. The end of 2014 witnessed a rapid depreciation of the ruble, the prices of goods and services continue to increase. In these circumstances many government and commercial projects for the modernization of production, especially on the basis of modern scientific and technical achievements, are terminated. The federal and regional budgets experience great hardship.

There is a real threat to stay forever in the raw materials periphery of the world market. The escalation of international tension on the part of the countries that represent the core of the global financial system is a great burden for our country. In response to Russia's actions that satisfied the constitutional will of the population of Crimea and Sevastopol in their desire to join Russia (backed by the overwhelming majority of the Russians), the U.S. and its allies in Western Europe are expanding their political and economic sanctions against our country.

Analyzing this situation, many experts, public figures and politicians especially emphasize the low efficiency of public 
administration ${ }^{2}$. The main reason for this they see in the fact that in Russia there is an interpenetration of oligarchic business, officialdom at all levels and lobbyists; this does not lead to the reduction of social inequality to a reasonable level (5-6 times, as in Germany and France), but, rather, it results in the widening of this gap, which currently exceeds 16 times. The sources of

\footnotetext{
2 Aganbegyan A.G. Sotsial'no-ekonomicheskoe razvitie Rossii: analiz i prognoz [Socio-Economic Development of Russia: Analysis and Forecast]. Problemy prognozirovaniya [Problems of Forecasting], 2014, no. 4; Amosov A. Mozhno li otlozhit' do 2017 g. povorot k novomu industrial'nomu razvitiyu [Is It Possible to Delay the Shift to a New Industrial Development until 2017]. Ekonomist [Economist], 2015, no. 3; Belkin V.D., Storozhenko V.P. Vykhod iz stagnatsii s pomoshch'yu uskorennogo razvitiya potrebitel'skoi sfery [Overcoming Stagnation through the Accelerated Development of Consumer Sector]. Ekonomicheskaya nauka sovremennoi Rossii [Economic Science of Modern Russia], 2014, no. 1; Bogomolov O.T. Problemy ispol'zovaniya neekonomicheskogo potentsiala modernizatsii. Institutsional'naya ekonomika otvergaet rynochnyi fundamentalizm [Problems of Using the Non-Economic Potential of Modernization. Institutional Economics Rejects Market Fundamentalism]. Vestnik RAN [Herald of RAS], 2013, vol. 83, no. 8; Gubanov S.S. Neoindustrializatsiya Rossii i nishcheta ee sabotazhnoi kritiki [Neo-Industrialization of Russia and the Poverty of Its Sabotage Criticism]. Ekonomist [Economist], 2014, no. 4; Delyagin M.G. Krakh optimisticheskikh illyuzii i otpravnoi punkt ekonomicheskogo ozdorovleniya [Collapse of Optimistic Illusions and the Starting Point for Economic Recovery]. Rossiiskii ekonomicheskii zhurnal [Russian Economic Journal], 2014, no. 1; Knyazev Yu. Perspektivy vykhoda iz krizisnoi stagnatsii [Prospects for Overcoming the Crisis Stagnation]. Mir peremen [World of Transformations], 2014, no. 4, pp. 1428; Na puti k sovremennoi dinamichnoi i effektivnoi ekonomike: doklad [Towards a Modern Dynamic and Efficient Economy: Report]. Ed. by A.D. Nekipelov, V.V. Ivanter, S.Yu. Glazyev (25 Corresponding Members of RAS participated in the preparation of the report). Moscow: RAN, 2013; Ot krizisnykh potryasenii i razrushitel'nykh reform - k razvitiyu: chto dolzhno sdelat' gosudarstvo, chtoby pokonchit' s krizisom v 2015 godu (Doklad Instituta problem globalizatsii) [From Crisis Shocks and Destructive Reforms - to Development: What the Government Should Do to End the Crisis in 2015 (Report of the Institute for Globalization Problems)]. Rossiiskii ekonomicheskii zhurnal [Russian Economic Journal], 2014, no. 1; Polterovich V.M. Kuda idti: dvadtsat' chetyre tezisa [Where to Go: 24 Theses]. Ekonomicheskaya nauka sovremennoi Rossii [Economic Science of Modern Russia], 2014 , no. 3 .
}

this inequality are found in the outrageous violation of the principles of social justice during the "Chubais privatization". The huge state property created by the labor and sacrifices of many generations of the Russian citizens, was distributed among the immediate environment of the federal government.

It appears that the crisis phenomena in economic, social and administrative spheres of the country can be mitigated, but they cannot be overcome without changing the dominant economic model, under which the economic and political elite at all levels is not focused on improving economic and political efficiency, and most importantly - on the increase of the level of social justice in the society.

One of the prominent expert scientists points out in this regard: "The current Russian crisis is systemic, it arises from the mismatch between the system and the requirements to the development of the society and its inability to develop positively. It is based on a deep conflict of interests of the elite and the objectives of social progress, when part of the elite is turned into its beneficiaries. The country has built the entire process of post-socialist transformation of the society in such a way that it has not managed to avoid the formation of this deep conflict and still cannot overcome it. This situation has been evolving rapidly since the beginning of the 1990s and was fully established in the last decade and a half"3.

3 Mikul'skii K. Ekonomika Rossii i protivorechiya ee obshchestvennogo ustroistva [Russia's Economy and the Contradictions of Its Social Structure]. Obshchestvo $i$ ekonomika [Society and Economics], 2014, no. 12. 
Ilyin V.A.

An authoritative political columnist M. Antonov in his article "The New Russia and Yeltsinism are incompatible" ${ }^{4}$ writes about the need to overcome a deep internal conflict in the Russian society. Using perfectly competent and evidence-based data, he comes to the conclusion that if even a bit of Yeltsinism is preserved, it will threaten Russia with serious internal turmoil.

Another expert says: "Our country urgently needs a new course, it needs completely new personnel in the government and in the presidential administration we need to renounce the orientation exclusively on the "Yeltsin legacy" with oligarchs of the RSPP... the top official of today's Russia is finally and irrevocably sentenced to elimination by the Western elites, who believe that Putin and no one else is the main obstacle in implementing the strategic vision of the "Washington regional committee" on the establishment of a single global government and the political fragmentation of Russia, required for that porpose" ${ }^{\text {. }}$

We think that, taking into consideration Vladimir Putin's life experience ${ }^{6}$, his 15 years of work in Russia's senior government positions, and the high level of trust of the voters, the President will be able to lead the country out of acute internal and external political problems to a new level of development, corresponding to the $21 \mathrm{st}$ century and the traditions of the "Russian world".

To resolve this problem, Vladimir Putin has three more years of his third presidential term and another six years of the possible fourth term - a total of nine years.

It would seem that there is still enough time, but it is a short period for serious and drastic changes in a country such as Russia.

Time is inexorably shrinking, like a magic piece of shagreen in the famous novel by Honor de Balzac.

It is time to start!

\footnotetext{
4 Antonov M. Novaya Rossiya i el'tsinizm nesovmestimy [The New Russia and Yeltsinism are Incompatible]. Literaturnaya gazeta [Literature Newspaper], 2015, no. 13 (6503), April 1-7.

5 Nagornyi A. Smert' tvoya za uglom: kurs dlya nezalezhnoi [Your Death is Waiting round the Corner: a Course for the Independent Country]. Zavtra [Tomorrow], 2015, no. 13, March-April.

6 Vladimir Putin was born in 1952 in Leningrad. After leaving high school in 1970 he enrolled in the international section of the law faculty at Leningrad State University. In 1975-1984, he worked at the Leningrad office of the KGB, in 1984-1985 he studied at the Institute of the KGB in the specialty "Foreign intelligence", in 1985-1990 he worked in the German Democratic Republic. After returning home in 1990-1991 he worked as international affairs assistant to the rector of Leningrad State University. In 1991-1992 he was Advisor to the Chairman of the Leningrad City Council, Chairman of the Committee of the Mayor's Office on Foreign Affairs, in 1993-1996 - Deputy Chairman of the Saint Petersburg Government. From August 1996 - Deputy Superintendent in the Office of the President of the Russian Federation, from March 1997 - Deputy Head of the Presidential Administration (Head of the Main Control Directorate), from May 1998 - first Deputy Head of the Presidential Administration. From July 1998 to August 1999 - Director of the FSB of Russia and Secretary of the Security Council of the Russian Federation. From August 1999 - Chairman of the Government of the Russian Federation, from December 31, 1999 - acting President of the Russian Federation. In 2000-2008 - President of the Russian Federation, in 2008-2012 - Chairman of the RF Government. In March 2012 - elected President of the Russian Federation for the third term, inaugurated on May 7, 2012.
} 